\title{
Spatial Evolution of Phosphorus Fractionation in the Sediments of Rhumel River in the Northeast Algeria
}

\author{
Sarah Azzouz ${ }^{1}$, Smaine Chellat ${ }^{2}$, Chahrazed Boukhalfa ${ }^{1}$ \& Abdeltif Amrane ${ }^{3}$ \\ ${ }^{1}$ Chemistry Department, University Constantine 1, Constantine, Algeria \\ ${ }^{2}$ Earth Science Department, University Kasdi Merbah, Ouargla, Algeria \\ ${ }^{3}$ Ecole Nationale Supérieure de Chimie de Rennes, Université Rennes1, CNRS, UMR 6226, Avenue du Général \\ Leclerc, CS 50837, 35708 Rennes Cedex 7, France
}

Correspondence: Chahrazed Boukhalfa, Chemistry Department, University Constantine 1, Constantine, Algeria. Tel: 213-550-398-389. E-mail: chahrazed_boukhalfa@yahoo.com

Received: September 10, 2013 Accepted: November 12, 2013 Online Published: December 5, 2013

doi:10.5539/ep.v3n1p51 URL: http://dx.doi.org/10.5539/ep.v3n1p51

\begin{abstract}
The objective of the present study is the characterization of the spatial evolution of phosphorus forms in sediments of Rhumel River located in northeast Algeria during winter conditions. Sediments samples were collected along the river in Constantine city during the year 2012. The samples were subjected to physicochemical characterization and metals analysis. Phosphorus was fractionated by sequential extractions procedure in exchangeable, oxyhydroxides bound; calcium bound; organic and residual fractions.

The distribution of the different forms of phosphorus in the sediments appears to be influenced by the physicochemical characteristics, which depend on the sampling location. Phosphorus speciation along the river is characterized by the predominance of inorganic phosphorus forms. The exchangeable fraction is the lowest. Phosphorus concentration in this fraction does not exceed $20 \mathrm{mg} / \mathrm{kg}$. The fraction bound to calcium is the most important in retaining inorganic phosphorus with concentrations varying from 328 to $490 \mathrm{mg} / \mathrm{kg}$. Phosphorus bound to oxyhydroxides represents an average of $172 \mathrm{mg} / \mathrm{kg}$. Along the river, the contribution of the different fractions in the phosphorus retention follows the order: exchangeable $<$ bound to oxyhydroxides $\sim$ organic $<$ bound to calcium < residual. As estimated by the sum of exchangeable, bound to oxyhydroxides and bound to organic matter, an average of about $28 \%$ of the total phosphorus can become bioavailable. The predominant fraction in the Rhumel sediments changes from residual at upstream Constantine city to bound to calcium at downstream from it.
\end{abstract}

Keywords: phosphorus, fractionation, mobility, sediment, Rhumel

\section{Introduction}

Phosphorus is an essential element in the functioning of aquatic ecosystems, it is considered as one of the major nutrients required by primary producers (Liu et al., 2012). However, it is also identified as a key nutrient responsible for eutrophication of aquatic environments which has become a serious environmental problem. Phosphorus is naturally present in the aquatic environment. It has various natural sources including leaching from rocks, drainage of forests and soil erosion. During the last century, the amount of phosphorus in freshwater has been greatly increased and amplified by human influence through industrial, agricultural and domestic activities. Sediments play an important role in the phosphorus cycle; they can adsorb large quantities of it and can also release it into the overlying water column when the concentration in water decreases and/or under the conditions of strong water dynamic or change of redox potential (Yang \& He, 2010). The nature of the chemical and physical links of phosphorus with sediments is the most important factor that governs its release. The mechanisms involved can be of chemical or biological nature or a combination of both (Slomp, Van Raaphorst, Malschaert, Kok, \& Sandee, 1993). Generally, phosphorus in sediments can be adsorbed by Fe, Al and Mn oxihydroxides, tied in organic substances and bound to calcium (Balzer, 1986). The mobilization of phosphorus can be affected by many factors such as temperature, dissolved oxygen, $\mathrm{pH}$ and the nature of the sediments (Hasnaoui et al., 2001). Under anoxic conditions, the release of the chemically bound phosphorus is due to 
reduction of iron oxides (Sallade \& Sims, 1997), mineralization of organic matter (Golterman, 1995) and acidification of sediments (Golterman, 1998).

The main objective of the present work is the evaluation of phosphorus mobility in the sediments of Rhumel River which traverses Constantine city in eastern Algeria. In our knowledge no such study has been undertaken in the area.

\section{Material and Methods}

\subsection{Study Site}

Rhumel River is located in the northeastern Algeria (Figure 1). It originates from the northwestern Bellaa in Setif. It traverses the high plains of Constantine, with an orientation southwest - northeast until Constantine city. Then, it suddenly changes the direction and turns to the right and flows obliquely towards the northwest (Mébarki, 1984), it confluences with the Oued Endja around Sidi Merouene in Mila town. The main tributary of the river is Oued Boumerzoug which drains industrial and urban zones.

The climate of the area is a semiarid type; characterized by wet winters and dry and hot summers. The quality of the river water is characterized by neutral to alkaline $\mathrm{pH}$ and high electrical conductivity.

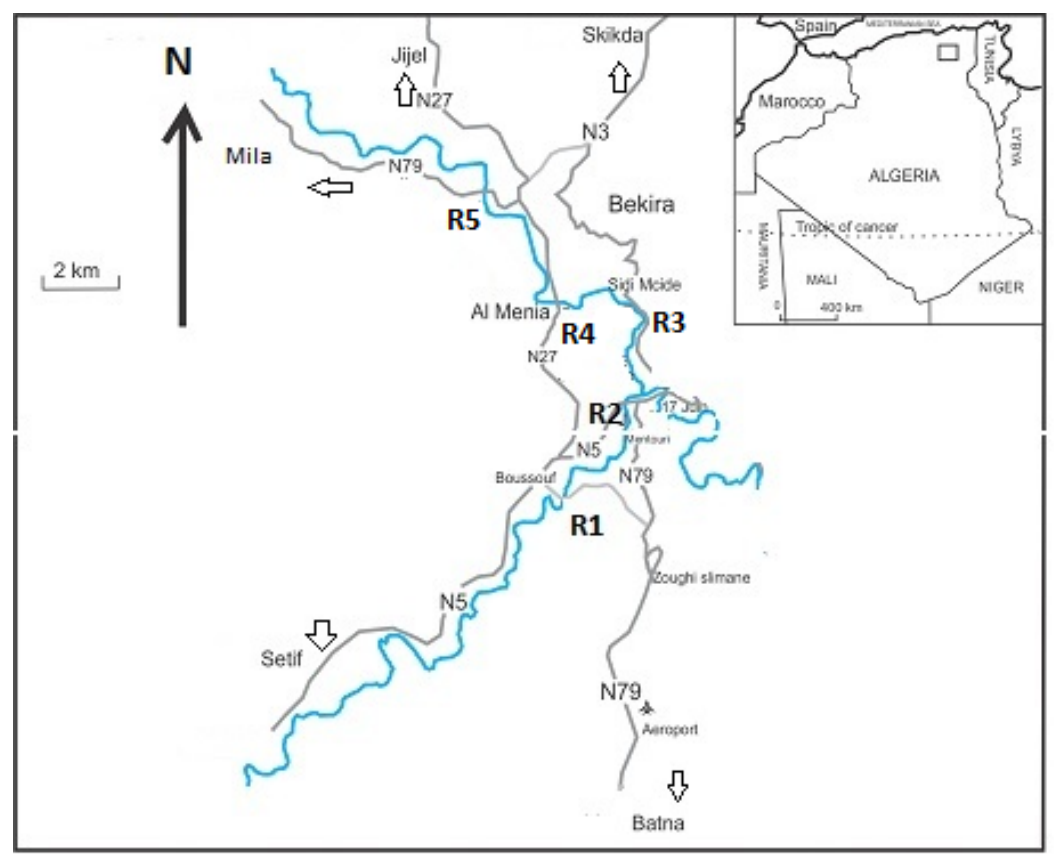

Figure 1. Localization of the Rhumel River and the sampling stations

\subsection{Samples Collection and Pretreatment}

The studied sediments were collected at five stations along the river (Figure 1, Table 1) in January 2012. Samples were placed in plastic bags and transported to the laboratory where they were dried at $40{ }^{\circ} \mathrm{C}$ then ground and sieved using a $0.215 \mathrm{~mm}$ sieve and conserved in polyethylene bottles until use.

Table1. Localization of the sampling stations

\begin{tabular}{lll}
\hline Location & Latitude & Longitude \\
\hline R1 & $36^{\circ} 19^{\prime} 37.15^{\prime \prime} \mathrm{N}$ & $6^{\circ} 35^{\prime} 37.65^{\prime \prime} \mathrm{E}$ \\
R2 & $36^{\circ} 20^{\prime} 53.45^{\prime \prime} \mathrm{N}$ & $6^{\circ} 36^{\prime} 49.61^{\prime \prime} \mathrm{E}$ \\
R3 & $36^{\circ} 22^{\prime} 22.80^{\prime \prime} \mathrm{N}$ & $6^{\circ} 36^{\prime} 41.47^{\prime \prime} \mathrm{E}$ \\
R4 & $36^{\circ} 22^{\prime} 22.90^{\prime \prime} \mathrm{N}$ & $6^{\circ} 35^{\prime} 32.63^{\prime \prime} \mathrm{E}$ \\
R5 & $36^{\circ} 23^{\prime} 57.79 " \mathrm{~N}$ & $6^{\circ} 34^{\prime} 15.50^{\prime \prime} \mathrm{E}$ \\
\hline
\end{tabular}




\subsection{Physicochemical Characterization}

Measurements of $\mathrm{pH}$ and electrical conductivity were performed in suspensions formed with distilled water. Organic matter was determined by loss on ignition at $550^{\circ} \mathrm{C}$. The total phosphorus was extracted with $\mathrm{HCl}(3.5$ M) after calcination. Phosphorus was measured in extracts by UV-visible spectrophotometry using the method of Murphy and Riley (1962). In this method, orthophosphate ions react with molybdate to form a yellow phosphomolybdic complex. Ascorbic acid specifically reduced the phosphomolybdic complex to give a blue color. The absorbance was measured at $700 \mathrm{~nm}$ with a spectrophotometer Shimadzu UV-1650PC. The metals were determined after calcination and acid digestion by flame atomic absorption using an atomic absorption spectrometer Varian AA140.

\subsection{Fractionation of Phosphorus in Sediments}

The different forms of phosphorus were extracted using the fractionation procedure described by Hieltjes and Lijklema (1980). The target phases and the reagents used are illustrated in Table 2. Phosphorus in all extracts was determined by the method described above. All results are average values of triplicate determinations.

Table 2. Sequential extractions procedure

\begin{tabular}{ll}
\hline Target fraction & Extraction reagent \\
\hline Exchangeable & $\mathrm{NH}_{4} \mathrm{Cl}(1 \mathrm{M}) 2 \mathrm{~h}$ shaking \\
Bound to oxyhydroxides & $\mathrm{NaOH}(1 \mathrm{M}) 16$ h shaking \\
Bound to calcium & $\mathrm{HCl}(0.5 \mathrm{M}) 16 \mathrm{~h}$ shaking \\
Organic & $\mathrm{Calcination}$ at $550^{\circ} \mathrm{C} 3 \mathrm{~h}$, \\
& $\mathrm{HCl}(1 \mathrm{M}) 16 \mathrm{~h}$ shaking \\
\hline
\end{tabular}

\section{Results and Discussion}

\subsection{Physicochemical Characterization}

The physicochemical results are presented in Table 3. The sampled sediments have an alkaline $\mathrm{pH}$ reflecting the dominance of limestone and clay and the buffering capacity associated with these sedimentary materials (Nassali, Ben bouih, \& Srhiri, 2002). At the first sampling station (R1), the lowest $\mathrm{pH}$ and the highest electrical conductivity are observed, showing the effect of the industrial zone located upstream. Generally, high values of electrical conductivity of the sediments are due to the enrichment by monovalent and divalent ions (Nassali et al., 2002). The low water contents reflect a low fluidity of these sediments (Abdallaoui, Derraz, Bhenabdallah, \& Lek, 1998). The important organic matter contents ranging from $4 \%$ to $6 \%$ are probably due to the degradation of dead cells of the fauna and flora within the River and leaching of surrounding soils (Abdellaoui, 1998).

Calcium is the most abundant element in the studied sediments. The measured concentrations of this metal ranged from $134.48 \mathrm{~g} / \mathrm{kg}$ to $182.35 \mathrm{~g} / \mathrm{kg}$. The Rhumel sediments are quite rich in iron and aluminum. The concentrations of the two metals vary between $15 \mathrm{~g} / \mathrm{kg}-20 \mathrm{~g} / \mathrm{kg}$ and $13 \mathrm{~g} / \mathrm{kg}-18 \mathrm{~g} / \mathrm{kg}$ respectively. Generally, the metals concentrations in the Rhumel sediments follow the order $\mathrm{Mn}<\mathrm{Al}<\mathrm{Fe}<\mathrm{Ca}$. Along the river, only calcium and manganese show a linear correlation in their spatial evolution (R: 0.86). Concentrations of total phosphorus vary from one site to another. The higher contents are observed at the two stations R1 and R4 located downstream the industrial zone and Constantine city respectively. Along the river, phosphorus is correlated with organic matter. The spatial evolution of its total concentration shows a decrease downstream. Phosphorus concentrations found in this study are similar to those measured in Oued D'Kor $(1287 \mathrm{mg} / \mathrm{kg})$ and Oued Beht (1343 mg/kg) in Morocco (Abdallaoui, 1998). 
Table 3. Physicochemical analysis of sediments of Rhumel River

\begin{tabular}{lccccc}
\hline Sample & $\mathrm{R} 1$ & $\mathrm{R} 2$ & $\mathrm{R} 3$ & $\mathrm{R} 4$ & $\mathrm{R} 5$ \\
\hline $\mathrm{pH}$ & 7.75 & 8.34 & 8.11 & 8.00 & 8.01 \\
Electrical Conductivity $(\mu \mathrm{s} / \mathrm{cm})$ & 1703 & 482 & 488 & 786 & 792 \\
Water content $(\%)$ & 3.25 & 2.61 & 2.05 & 1.31 & 0.89 \\
Loss on ignition $(\%)$ & 8.76 & 6.84 & 7.23 & 7.48 & 5.23 \\
Total phosphorus $(\mathrm{mg} / \mathrm{kg})$ & 1568 & 1140.29 & 1337.74 & 1547.98 & 1115.13 \\
$\mathrm{Ca}(\mathrm{g} / \mathrm{kg})$ & 146.01 & 182.35 & 134.48 & 143.77 & 141.86 \\
$\mathrm{Fe}(\mathrm{g} / \mathrm{kg})$ & 15.66 & 16.97 & 17.95 & 19.61 & 20.77 \\
$\mathrm{Al}(\mathrm{g} / \mathrm{kg})$ & 18.43 & 15.66 & 12.95 & 14.58 & 13.70 \\
$\mathrm{Mn}(\mathrm{mg} / \mathrm{kg})$ & 324.50 & 367.34 & 245.28 & 261.04 & 234.38 \\
\hline
\end{tabular}

\subsection{Fractionation of Phosphorus in Sediments}

The used sequential fractionation scheme (Hieltjes \& Lijklema, 1980) allowed us to distinguish five fractions: soluble phosphorus; phosphorus bound to iron, aluminum and manganese oxyhydroxides; phosphorus bound to calcium; organic phosphorus and residual fraction. The last fraction is calculated as the difference between total phosphorus and the sum of the four other fractions.

\subsubsection{Spatial Evolution of Soluble Fraction}

The exchangeable fraction represents mineral fraction adsorbed on exchange sites (Hieltjes \& Lijklema, 1980), directly assimilated by algae. It is the most available fraction. In the Rhumel sediments (Figure 2), the soluble phosphorus does not exceed $20 \mathrm{mg} / \mathrm{kg}$. The highest value is observed at the sampling station R4 and can be attributed to the settlement of finer particles due to slower water flow (Yang, He, Lin, \& Stoffella, 2010). Low values of soluble phosphorus concentration have also been found in other studies (Salvia-Castellvi, Scholer, \&Hoffmann, 2002; Taoufik \& Dafir, 2002; Taoufik, Kemmou, Loukili Idrissi, \& Dafir, 2004; Kemmou, Dafir, Wartiti, \& Taoufik, 2006).

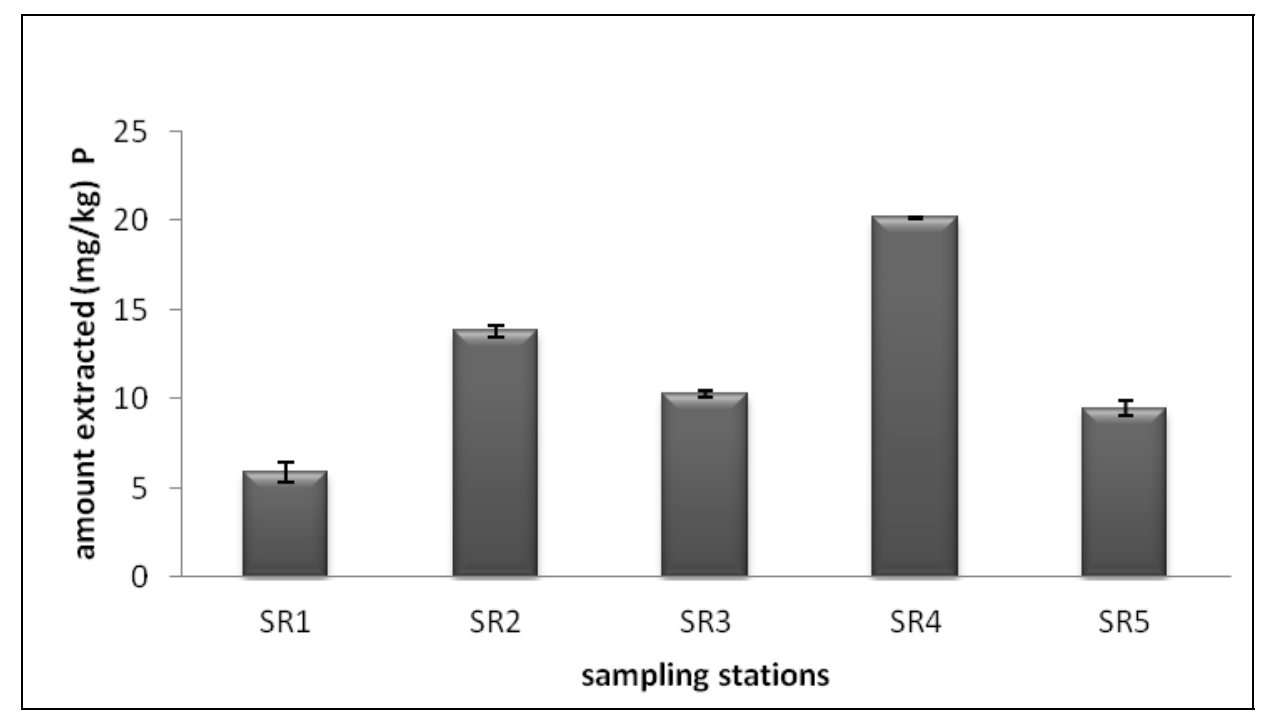

Figure 2. Spatial evolution of the exchangeable fraction 


\subsubsection{Spatial Evolution of the Fraction Bound to Oxyhydroxides}

In the sediments, phosphorus is frequently associated with $\mathrm{Fe}, \mathrm{Al}$ and $\mathrm{Mn}$ oxides and hydroxides (Pardo, Lopez-Sanchez, \& Rauret, 2003). This fraction plays an important role in phosphorus exchange at the sediment-water interface (Kemmou et al., 2006). It is easily mobilized and is responsible for an increase of eutrophication (Zhou, Gibson, \& Zhu, 2001). In the Rhumel sediments, concentrations of phosphorus extracted by $\mathrm{NaOH}$ ranged from $130 \mathrm{mg} / \mathrm{kg}$ to $221 \mathrm{mg} / \mathrm{kg}$ (Figure 3). The spatial evolution of this fraction shows that phosphorus is more closely related to $\mathrm{Fe}$ than $\mathrm{Al}$ and $\mathrm{Mn}$. Consequently, anoxic conditions mediated by bacteria result in the release of sorbed phosphorus from iron oxyhydroxides. The Fe/P ratio of 2 has been regarded as a threshold of phosphorus saturation in soil or sediments (Blomqvist, Gunnars, \& Elmgren, 2004). Elsewhere, the molar ratio $\mathrm{P} /(\mathrm{Fe}+\mathrm{Al})$ has been considered as a better indicator of the potential availability of phosphorus in river sediments (Nair, Portier, Graetz, \& Walker, 2004). In the present study, Fe/P ratios are above 2; the highest calculated value concern the sediments collected downstream from Constantine city. The calculated $\mathrm{P} /(\mathrm{Fe}+\mathrm{Al})$ molar ratios vary around 0.05 implying the importance of phosphorus immobilization along the river.

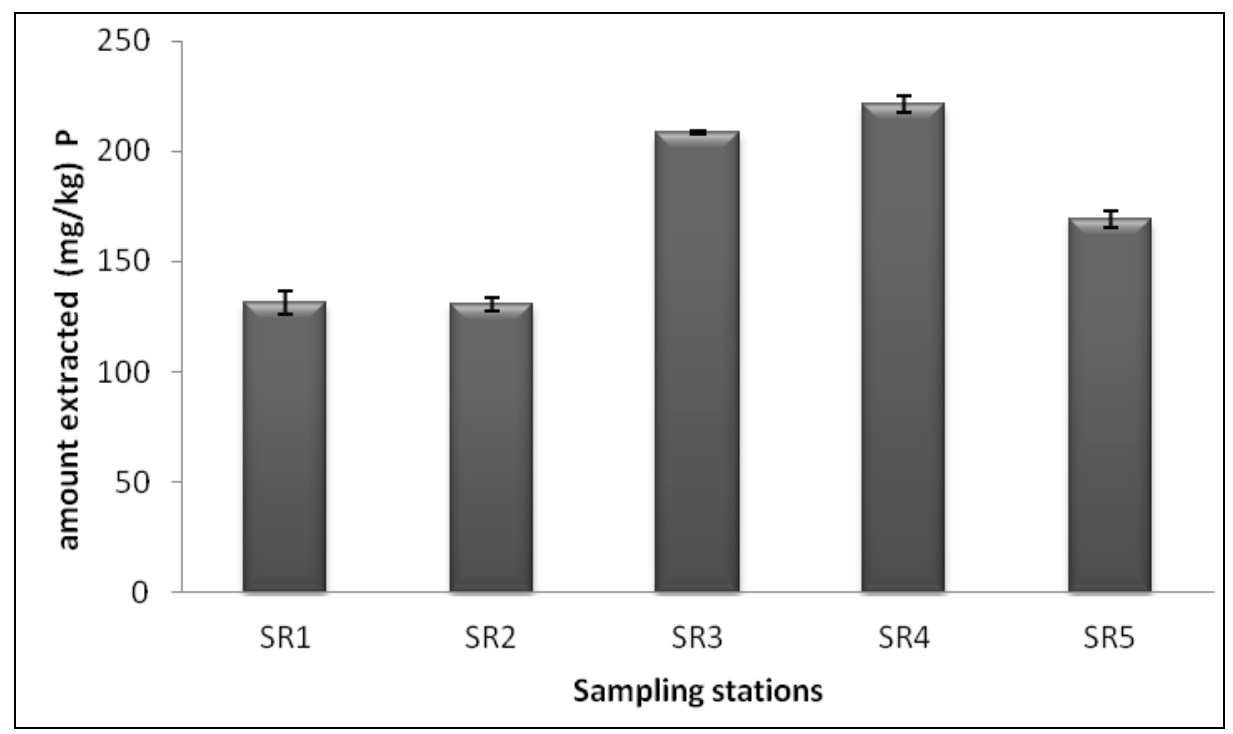

Figure 3. Spatial evolution of oxyhydroxides bound fraction

\subsubsection{Spatial Evolution of the Fraction Bound to Calcium}

This fraction is sensitive to low $\mathrm{pH}$. It is assumed to be composed mainly of calcium bound phosphorus as apatite such as $\mathrm{Ca}_{5}\left(\mathrm{PO}_{4}\right)_{3}(\mathrm{OH}, \mathrm{F}, \mathrm{Cl})$ and phosphorus bound to calcium carbonate. The first fraction is highly insoluble and redox-insensitive; it can only be attacked by strong acids (Smolders et al., 2006). The Rhumel sediments are characterized by high concentrations of phosphorus bound to calcium varying from $328.35 \mathrm{mg} / \mathrm{kg}$ to $490.79 \mathrm{mg} / \mathrm{kg}$ (Figure 4). This is related to the significant calcium contents (Table 2). According to Golterman (1995), when sediments are acidified a part of the phosphorus bound to calcium carbonate might be solubilized. In the present study, $\mathrm{pH}$ does not vary significantly. Consequently, this fraction is the most uniform along the river. Generally, phosphorus bound to calcium is considered as the main route of permanent storage of phosphorus in sediments and soils (Gonsiorczyk, Casper, \& Koschel, 1998). This fraction is released from sediments with difficulty. Consequently, it is not easily used by algae (Kozerski \& Kleeberg, 1998; Kaiserli, Voutsa, \& Samara, 2002). 


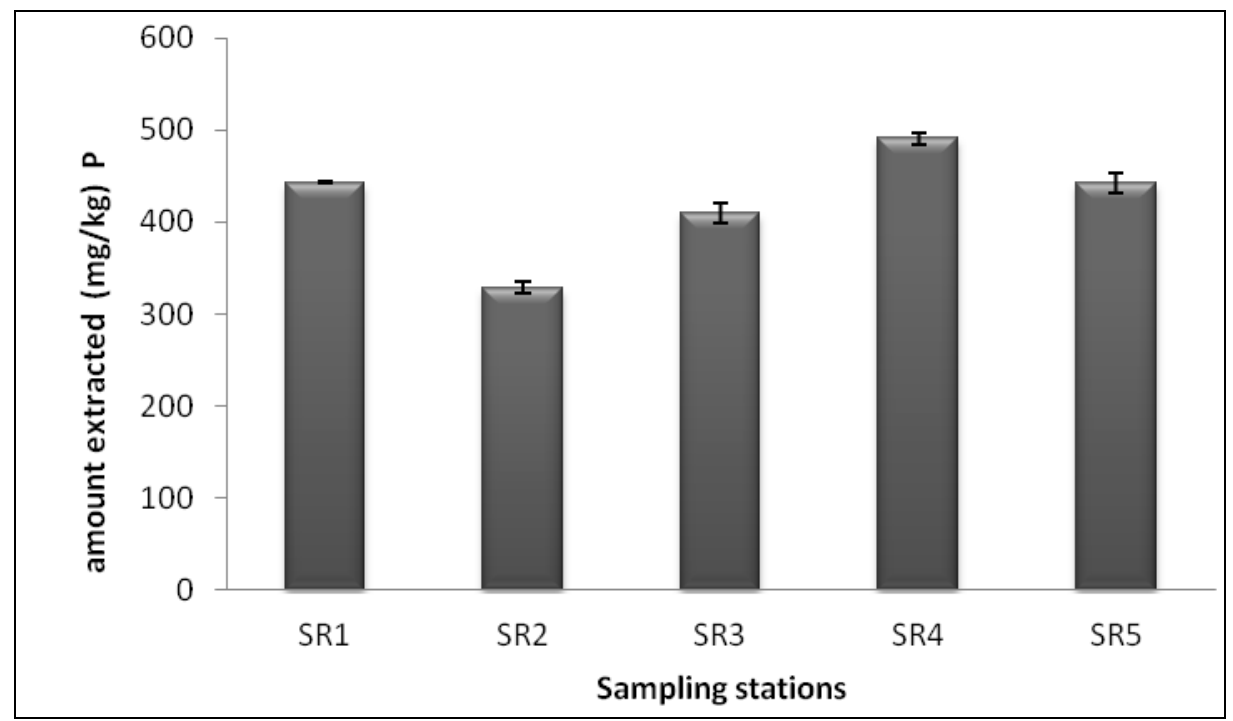

Figure 4. Spatial evolution of calcium bound fraction

\subsubsection{Spatial Evolution of Organic Fraction}

In the studied sediments, concentrations of organic phosphorus are lower than those of inorganic phosphorus (Figure 5). The spatial distribution of this fraction is generally similar to that of the organic matter. At the sampling stations located in the urban area (R2, R3, R4), a marked increase in organic phosphorus is observed. An increase in the organic matter amount of the sediment leads to an increase in the amount of associated phosphorus. It has been suggested that organic phosphorus in sediments is predominantly associated with humic material by complexation and chelation reactions involving metallic cations (Garcia \& de Iorio, 2003). The complexes of organic matter with iron can also adsorb phosphorus (Kemmou et al., 2006). Under anoxic conditions, the organic fraction can become bioavailable after sediments mineralization.

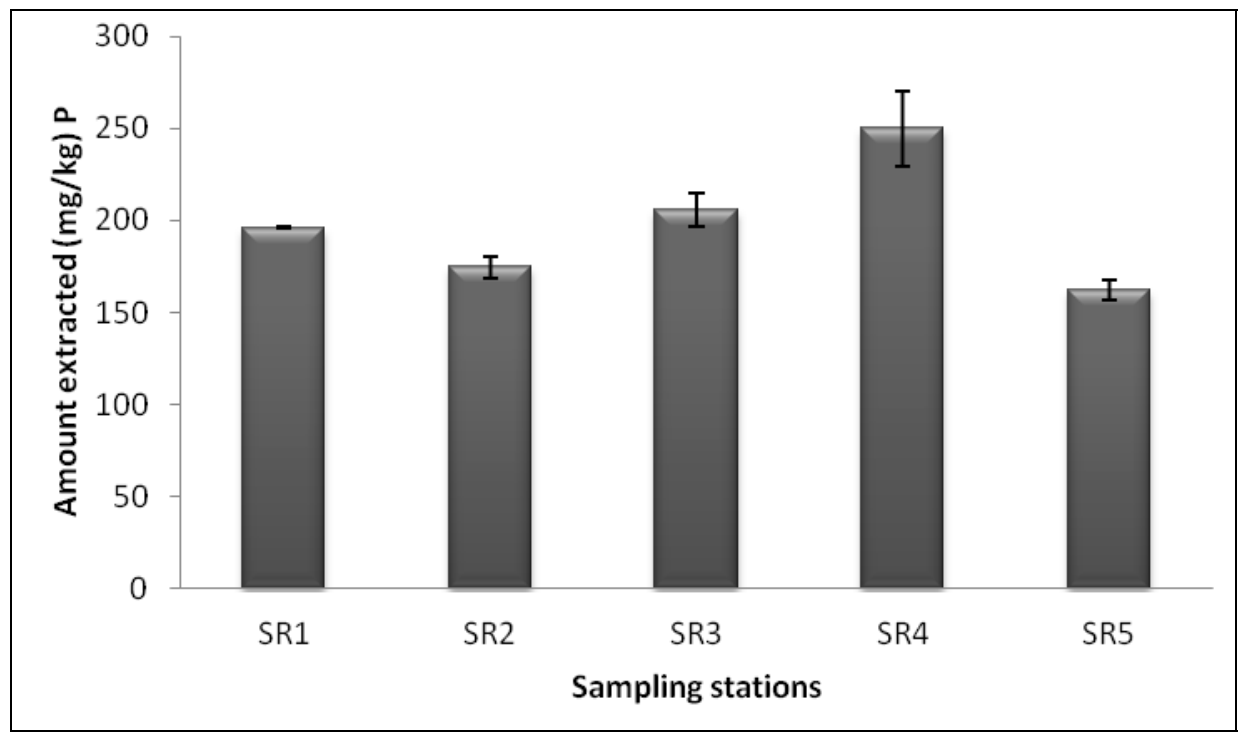

Figure 5. Spatial evolution of organic fraction

\subsubsection{Distribution of Phosphorus in the Sediments}

The speciation of sedimentary phosphorus in Rhumel River (Figure 6), show that it is mostly in inorganic forms. Along the river, the exchangeable form is the lowest compared to the other fractions. Phosphorus availability in the Rhumel sediments appeared to be related to phosphorus sorption by oxyhydroxides and complexation with organic material. Upstream the confluence with Boumerzoug tributary (R1, R2), the contribution of the organic 
fraction is more important than the one of the oxyhydroxides. However at downstream, the two fractions are closer. The fraction related to calcium is the most important part of the inorganic phosphorus. It has been suggested that the high phosphorus contents of this fraction could be also explained by the fact that a part of phosphorus extracted with $\mathrm{NaOH}$ is readsorbed on calcium (De Groot, \& Golterman, 1990). In addition, a part of the organic fraction can be solubilized by acid extraction resulting in an overestimation of the phosphorus amount extracted during this step. The contribution of the residual fraction decreases along the river. In this fraction, phosphorus can be associated to crystalline iron oxides, silicates (Buffle, de Vitre, Perret, \& Leppard, 1989) and crystalline aluminum-silicate species (Jonsson, 1997). The predominant phosphorus fraction in the Rhumel sediments changes from residual at upstream of Constantine city to bound to calcium downstream from it.

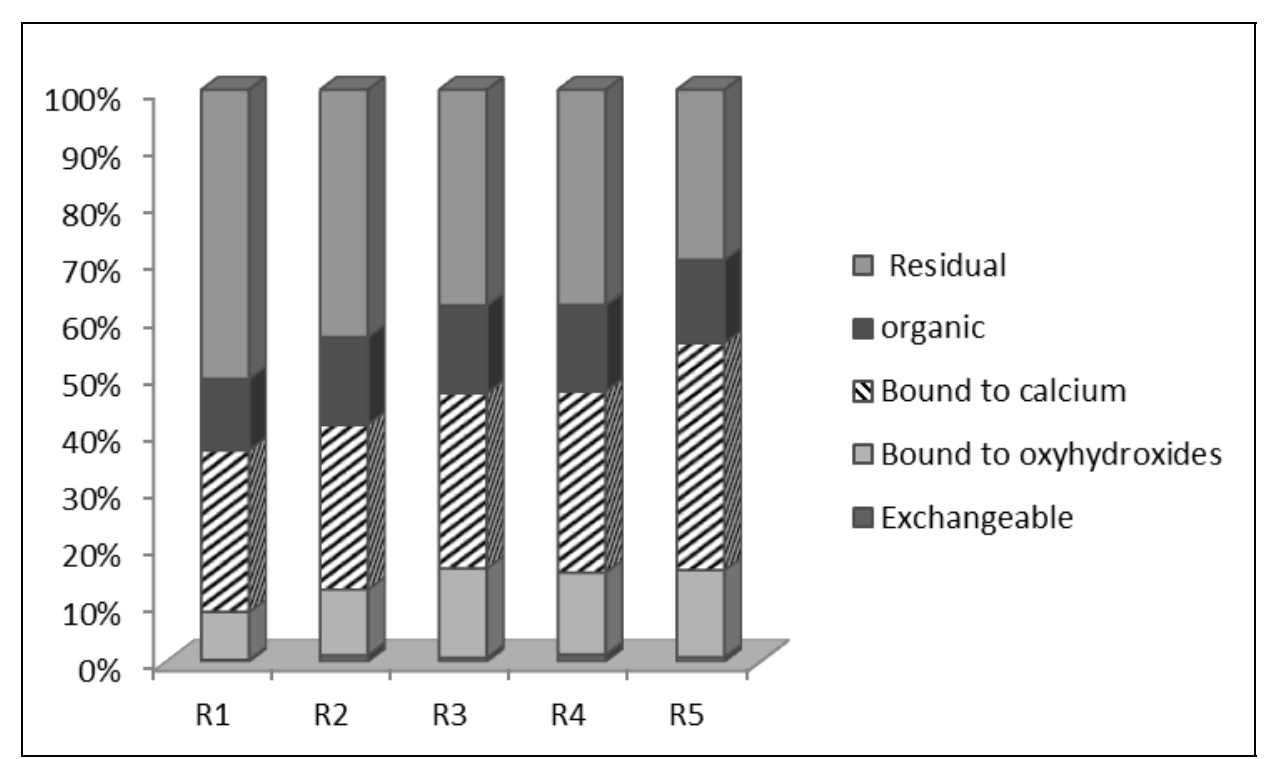

Figure 6. Spatial evolution of phosphorus distribution in Rhumel sediments

\section{Conclusion}

Sedimentary phosphorus in Rhumel River is mainly inorganic. The fraction directly available is the lowest. The two fractions, residual and bound to calcium considered as permanents, are the most important. As estimated by the sum of exchangeable, bound to oxyhydroxides and bound to organic matter, about $28 \%$ of the total phosphorus in Rhumel sediments can become bioavailable.

\section{Acknowledgements}

Authors thanks Mrs Oughebbi Laurence for her assistance in the analyses of metals.

\section{References}

Abdallaoui, A. (1998). Contribution à l'étude du phosphore et des métaux lourds contenusdans les sédimentset de leur influence sur les phénomènes d'eutrophisation et de la pollution. Cas du bassin versant de l'oued Beht et de la retenue de barrage El Kansera. PHD Thesis, Marroco. Retrieved from http://toubkal.imist.ma/handle/123456789/7171

Abdallaoui, A., Derraz, M., Bhenabdallah, M. Z., \& Lek, S. (1998). Contribution à l'étude de la relation entre les Différentesformes du phosphore dans les sédiments d'une retenue de barrage eutrophe en climat méditerranéen (El Kansera, Maroc). Revue des sciences de l'eau, 11, 101-116. http://dx.doi.org/10.7202/705299ar

Balzer, W. (1986). Forms of phosphorus and its accumulation in coastal sediments of Kieler Bucht. Ophelia, 26, 19-35. http://dx.doi.org/10.1080/00785326.1986.10421976

Blomqvist, S., Gunnars, A., \& Elmgren, R. (2004). Why the limiting nutrient differs between temperate coastal seas and freshwater lakes: a matter of salt. Limnol. Oceanogr, 49, 2236-2241. http://dx.doi.org/10.4319/lo.2004.49.6.2236 
Buffle, J., De Vitre, R. R., Perret, D., \& Leppard, G. G. (1989). Physico-chemical characteristics of a colloidal iron phosphate species formed at the oxic-anoxic interface of a eutrophic lake. Geochimica et Cosmochimica Acta, 53, 399-408. http://dx.doi.org/10.1016/0016-7037(89)90391-8

De Groot, C. J., \& Golterman, H. L. (1990). Sequential fractionation of sediment phosphate. Hydrobiologia, 192, 143-148. http://dx.doi.org/10.1007/BF00006010

Garcia, A. R., \& de Iorio, A. F. (2003). Phosphorus distribution in sediments of Morales Stream (tributary of the Matanza-Riachuelo River, Argentina). The influence of organic point source contamination. Hydrobiologia, 492, 129-138. http://dx.doi.org/10.1023/A:1024874030418

Golterman, H. L. (1995). The labyrinth of nutrient cycles and buffers in wetlands: results based on research in theCamargue (southern France). Hydrobiologia, 315, 39-58. http://dx.doi.org/10.1007/BF00028629

Golterman, H. L. (1998). Presence of and phosphate release from polyphosphates or phytate phosphate in lake sediments. Hydrobiologia, 364, 99-104. http://dx.doi.org/10.1023/A:1003212908511

Gonsiorczyk, T., Casper, P., \& Koschel, R. (1998). Phosphorus binding forms in the sediment of an oligotrophic and an eutrophic hardwater lake of the Baltic district (Germany). Water Science and Technology, 37, 51-58. http://dx.doi.org/10.1016/S0273-1223(98)00055-9

Hasnaoui, M., Kassila, J., Loudiki, M., Droussi, M., Balvay, G., \& Barrouin, G. (2001). Relargage du phosphore à l'interface eau-sédiment dans des étangs de pisciculture de la station Deroua (Béni Mellal, Maroc). Revue des sciences de l'eau, 14, 307-322. http://dx.doi.org/10.7202/705422ar

Hieltjes, A. H. M., \& Lijklema, L. (1980). Fractionation of inorganic phosphate in calcareous sediments. $J$. Env.Qual., 9, 405-407. http://dx.doi.org/10.2134/jeq1980.93405x

Jonsson, A. (1997). Fe and Al sedimentation and their importance as carriers for $\mathrm{P}, \mathrm{N}$ and $\mathrm{C}$ in a large humic lake in northern Sweden. Water Air Soil Pollut, 99, 283-295. http://dx.doi.org/10.1007/BF02406868

Kaiserli, A., Voutsa, D., \& Samara, C. (2002). Phosphorus fractionation in lake sediments-Lakes Volvi and koronia N. Greece. Chemosphere, 46, 1147-1155. http://dx.doi.org/10.1016/S0045-6535(01)00242-9

Kemmou, S., Dafir, J. E., Wartiti, M., \& Taoufik, M. (2006).Variations saisonnières et mobilité potentielle du phosphore sédimentaire de la retenue de barrage Al Massira (Maroc). Water Qual. Res. J. Canada, 41, 427-436.

Kozerski, H. P., \& Kleeberg, A. (1998). The sediments and the benthic pelagic exchange in the shallow lake Muggelsee. Int Rev Hydrobiol, 83, 77-112. http://dx.doi.org/10.1002/iroh.19980830109

Liu, L., Zhang, Y., Efting, A., Barrow, T., Qian, B., \& Fang, Z. (2012). Modeling bioavailable phosphorus via other phosphorus fractions in sediment cores from Jiulongkou Lake, China. Environ Earth Sci., 65, 945-956. http://dx.doi.org/10.1007/s12665-011-1295-2

Mébarki, A. (1984). Ressources en eau et aménagement en Algérie. Le bassin du Kébir-Rhumel. Alger, Office des Publications Universitaires.

Murphy, J., \& Riley, J. (1962). A modified single method solution method for the determination of phosphates in natural water. Anal. Chim. Acta, 27, 31-36. http://dx.doi.org/10.1016/S0003-2670(00)88444-5

Nair, V. D., Portier, K. M., Graetz, D. A., \& Walker, M. L. (2004). An environmental threshold for degree of phosphorus saturation in sandy soils. J. Environ. Qual., 33, 107-113. http://dx.doi.org/10.2134/jeq2004.1070

Nassali, H., Ben bouih, H., \& Srhiri. A. (2002). Influence des eaux usées sur la dégradation de la qualité des eaux $\mathrm{du}$ lac Fouarate au maroc. Proceedings of International Symposium on Environmental Pollution Control and Waste Management. Tunis (EPCOWM), 3-14. Retrieved from http://www.geocities.jp/epcowmjp/EPCOWM2002/Volume1.htm

Pardo, P., Lopez-Sanchez, J. F., \& Rauret, G. (2003).Relationships between phosphorus fractionation and major components in sediments using the SMT harmonized extraction procedure. Analytical and Bioanalytical Chemistry, 376, 248-254.

Sallade, Y. E., \& Sims, J. T. (1997). Phosphorus transformations in the sediments of Delawareps Agricultural Drainageways: Effect of reducing conditions on phosphorus release. J. Envir. Qual., 26, 1579-1588. http://dx.doi.org/10.2134/jeq1997.00472425002600060018x 
Salvia-Castellvi, M., Scholer, C., \& Hoffmann, L. (2002). Comparaison de différents protocoles de spéciation séquentielle du phosphore dans des sédiments de rivière. Revue des sciences de l'eau, 15, 223-233. http://dx.doi.org/10.7202/705448ar

Slomp, C. P., Van Raaphorst, W., Malschaert, J. F. P., Kok, A., \& Sandee, A. J. J. (1993). The effect of deposition of organic matter on phosphorus dynamics in experimental marine sediment systems. Hydrobiologia, 253, 83-98. http://dx.doi.org/10.1007/BF00050724

Smolders, A. J. P., Lamers, L. P. M., Lucassen, E., Van Der Velde, G., \& Roelofs, J. G. M. (2006). Internal eutrophication: how it works and what to do about it, a review. Chem. Ecol., 22(2), 93-111. http://dx.doi.org/10.1080/02757540600579730

Taoufik, M., \& Dafir, J. E. (2002). Comportement du phosphore dans le sédiment des barrages de la partie aval du bassin versant d'Oum Rabiaa (Maroc). Revue des sciences de l'eau, 15, 235-249. http://dx.doi.org/10.7202/705449ar

Taoufik, M., Kemmou, S., Loukili Idrissi, L., \& Dafir, J. E. (2004). Comparaison de deux méthodes de spéciation du phosphore dans des sédiments de la partie aval du basin Oum Rabiaa (Maroc). Water Qual. Res. J. Canada, $39,50-56$.

Yang, Y. G., He, Z. L., Lin, Y., \& Stoffella, P. J. (2010). Phosphorus availability in sediments from a tidal river receiving runoff water from agricultural fields. Agricultural Water Management, 97, 1722-1730. http://dx.doi.org/10.1016/j.agwat.2010.06.003

Zhou, Q., Gibson, C. E., \& Zhu, Y. (2001). Evaluation of phosphorus bioavailability in sediments of three contrasting lakes in china and UK. Chemosphere, 42, 221-225. http://dx.doi.org/10.1016/S0045-6535(00)00129-6

\section{Copyrights}

Copyright for this article is retained by the author(s), with first publication rights granted to the journal.

This is an open-access article distributed under the terms and conditions of the Creative Commons Attribution license (http://creativecommons.org/licenses/by/3.0/). 